\title{
An atypical Silurian myodocope ostracod from the Armorican Massif, France
}

\author{
Vincent Perrier \\ Acta Palaeontologica Polonica 57 (2), 2012: 363-373 doi: http://dx.doi.org/10.4202/app.2010.0006
}

A new myodocope ostracod Sineruga insolita gen. et sp. nov. is herein described from the Armorican Massif (France). Sineruga resembles Silurian myodocopes (i.e., bolbozoids and cypridinids) in having anterior features (thinner carapace) possibly related to vision. On the other hand, it resembles entomozoid ostracods in having a bean-shaped outline along with a deep adductorial sulcus and a simple muscle spot, but lacks their characteristic ribbed ornament. The data available suggest that Sineruga insolita was probably an atypical, non-ribbed member of the entomozoids thus indicating that early entomozoids may have had smooth representatives. Comparisons with other Recent and fossils ostracods show that the presence of a rostrum and/or symmetrical vision related carapace features (i.e., indicating lateral eyes) can be used as diagnostic characters for myodocope ostracods. The position and shape of the dorsal connection and to a lesser extent that of the sulcus and the adductorial muscle scar can be used to discriminate the higher groups of Silurian myodocopes (bolbozoids, cypridinids, and entomozoids).

Key words: Arthropoda, Crustacea, Ostracoda, Myodocopa, Entomozoidae, taxonomy, Silurian, France.

Vincent Perrier [vincent.perrier@ut.ee] University of Tartu, Institute of Ecology and Earth Sciences Department of Geology, Ravila 14A, 50411 Tartu - Estonia.

This is an open-access article distributed under the terms of the Creative Commons Attribution License (for details please see creativecommons.org), which permits unrestricted use, distribution, and reproduction in any medium, provided the original author and source are credited. 
